\title{
OS CLUBES DE CIÊNCIAS COMO CONTEXTOS DE FORMAÇÃO INICIAL DOCENTE: CONTRIBUIÇÕES A PARTIR DA PRODUÇÃO CIENTÍFICA DE UM COLETIVO PIBID
}

\author{
Daniela Tomio ${ }^{1}$, Edson Schroeder ${ }^{2}$, Cintia Conzatti ${ }^{3}$, Bruna Hamann ${ }^{4}$, Natalia Bagatolli Pedron ${ }^{5}$ \\ ${ }^{1}$ Doutora em Educação Científica e Tecnológica pela Universidade Federal de Santa Catarina - UFSC, SC. Docente \\ pesquisadora nos Programas de Pós-graduação em Educação (PPGE) e Ensino de Ciências Naturais e Matemática \\ (PPGECIM) na Universidade Regional de Blumenau - FURB, SC. ORCID iD: https://orcid.org/0000-0001-5578-7822 E- \\ mail: danitomiobr@gmail.com \\ ${ }^{2}$ Doutor em Educação Científica e Tecnológica pela Universidade Federal de Santa Catarina - UFSC, SC. Docente \\ pesquisador nos Programas de Pós-graduação em Educação (PPGE) e Ensino de Ciências Naturais e Matemática \\ (PPGECIM) na Universidade Regional de Blumenau - FURB, SC. ORCID iD: https://orcid.org/0000-0001-8917-2017 E- \\ mail: ciencia.edson@gmail.com \\ ${ }^{3}$ Licencianda em Ciências Biológicas. Bolsista de Iniciação Científica pelo Conselho Nacional de Desenvolvimento \\ Científico e Tecnológico (CNPq) na Universidade Regional de Blumenau - FURB, SC. ORCID iD: https://orcid.org/0000- \\ 0002-5861-1168 E-mail: cintiaaconzatti@gmail.com \\ ${ }^{4}$ Mestranda no Programa de Pós-graduação em Ensino de Ciências Naturais e Matemática (PPGECIM) da Universidade \\ Regional de Blumenau - FURB, SC. ORCID iD: https://orcid.org/0000-0002-8623-761X E-mail: \\ brunaham@hotmail.com \\ ${ }^{5}$ Mestranda no Programa de Pós-graduação em Educação da Universidade Regional de Blumenau - FURB, SC. ORCID

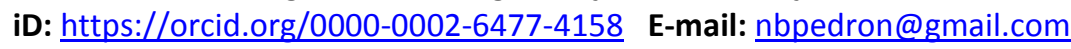

\section{RESUMO}

Esta pesquisa é desenvolvida de forma a articular compreensões sobre formação inicial de professores em contextos de Educação Não Formal, os Clubes de Ciências. Entre os anos 2014 a 2017, um coletivo de bolsistas do Programa Institucional de Bolsas de Iniciação à Docência, partilhou experiências docentes em Clubes de Ciências e em seu percurso escreveu sobre suas práticas educativas, disseminando-as em publicações. Diante disso, objetivamos elucidar, a partir de uma análise da produção científica desenvolvida por esse coletivo acerca de práticas educativas em Clubes de Ciências, contributos para a formação de professores. Para isso, realizamos uma pesquisa bibliográfica, com um inventário da produção científica desse coletivo e a interpretação dos dados, considerando categorias a priori elaboradas a partir dos "cinco focos de aprendizagem docente" e das "cinco posições para formação docente". Foram inventariados e analisados 65 trabalhos, divulgados em eventos locais, nacionais e um internacional. Sua análise nos permitiu interpretar que o movimento do PIBID, nas relações universidade-escola, potencializou os Clubes de Ciências constituírem-se espaços com potência formativa, possibilitando aos licenciandos experiências que mobilizaram a elaboração de conhecimentos práticos da docência (composição pedagógica) e sua reflexão (recomposição investigativa); o interesse pela docência (disposição pessoal), o cultivo de pertencimento à uma comunidade docente e o desenvolvimento da identidade docente (interposição profissional) em articulações da Educação Não Formal e a escola.

Palavras-chave: Formação de Professores. PIBID. Práticas educativas. Clubes de Ciências.

\section{SCIENCE CLUBS AS CONTEXTS OF INITIAL TEACHING TRAINING: CONTRIBUTIONS FROM THE SCIENTIFIC PRODUCTION OF A PIBID COLLECTIVE}

\section{ABSTRACT}

This research is developed in order to articulate understandings about the initial formation of teachers in contexts of Non-Formal Education, the Science Clubs. Between the years 2014 to 2017, a group of scholarship holders from the Institutional Scholarship Program for Teaching Initiation, shared teaching experiences in Science Clubs and in their recorded path about their educational practices, disseminating them in publications. Therefore, we aim to elucidate, based on an analysis of the scientific production 
developed by this group about educational practices in Science Clubs, contributions to the training of teachers. For this, we carried out a bibliographic research, with a study of the scientific production of this collective and the interpretation of the data, considering a priori categories elaborated from the "five focuses of teacher learning" and "five positions for teacher training". 65 works were inventoried and worked, disseminated at local, national and one international events. Its analysis in the budgets interpret that the PIBID movement, in university-school relations, strengthened Science Clubs to become spaces with formative power, enabling undergraduate students experiences that mobilized the preparation of practical teaching knowledge (pedagogical composition) and its reflection (investigative recompositing); the interest in teaching (personal disposition), the cultivation of belonging to the teaching community and the development of the teaching identity (professional interposition) in articulations of Non Formal Education and the school.

Keywords: Teacher Education, PIBID, Educational practices, Science Clubs.

\section{LOS CLUBES DE CIENCIA COMO CONTEXTOS DE LA FORMACIÓN DOCENTE INICIAL: CONTRIBUCIONES DESDE LA PRODUCCIÓN CIENTÍFICA DE UN COLECTIVO PIBID}

\section{RESUMEN}

Esta investigación se desarrolla con el objetivo de articular entendimientos sobre la formación inicial de profesores en contextos de Educación No Formal, los Clubes de Ciencias. Entre los años 2014 a 2017, un grupo de becarios del Programa Institucional de Becas de Iniciación a la Docencia, compartieron experiencias docentes en Clubes de Ciencias y escribieron sobre sus prácticas educativas, difundiéndolas en publicaciones. Por ello, pretendemos dilucidar, a partir de un análisis de la producción científica desarrollada por este colectivo sobre las prácticas educativas en los Clubes de Ciencias, las contribuciones a la formación de los docentes. Para ello, realizamos una investigación bibliográfica, con un inventario de la producción científica de este colectivo y la interpretación de los datos, considerando categorías a priori elaboradas a partir de los "cinco focos de formación docente" y "cinco posiciones para la formación docente". Se inventariaron y analizaron 65 obras, difundidas en eventos locales, nacionales e internacionales. Su análisis permitió interpretar que el movimiento PIBID, en las relaciones universidadescuela, ha empoderado a los Clubes de Ciencias para convertirse en espacios con poder formativo, permitiendo a los estudiantes de pregrado experiencias que movilizaron el desarrollo del conocimiento práctico docente (composición pedagógica) y su reflexión. (recomposición investigativa); el interés por la docencia (disposición personal), el cultivo de la pertenencia a una comunidad docente y el desarrollo de la identidad docente (interposición profesional) en las articulaciones de la Educación No Formal y la escuela.

Palabras clave: Formación Docente. PIBID. Prácticas educativas. Clubes de Ciencia.

\section{INTRODUÇÃO}

Como nos Clubes de Ciências, é fato que existem educadores em zoológicos, galerias de artes, museus, bibliotecas, organizações não governamentais, entre tantos outros lugares, desenvolvendo suas práticas educativas em cenários, espaços e tempos distintos dos modelos de educação formal. São educadores que cotidianamente convivem com estudantes, mas não têm uma escola como lugar de trabalho.

Se a Educação Não Formal (ENF) é espaço onde atuam educadores, configurando-se em lócus de uma prática educativa com suas especificidades, como então ocorrem seus processos de formação desse profissional da Educação? "Tal indagação se dá em meio aos desafios do século 21 , cenário de novas configurações pedagógicas que criam e recriam diferentes possibilidades de ensinar e aprender, tornando ainda mais complexo o significado e as formas de educação" (SEVERO, 2015, p. 564).

Nesta direção, compartilhamos de pressupostos de Nóvoa (2009) de que a escola do nosso tempo (presente e seu pensar para o futuro) precisa ser compreendida em seu lugar como um espaço público não hegemônico e na possibilidade de articular-se com outras formas sociais de educação. Conforme Gohn (2010, p. 22),

[...] a Educação Não Formal não tem o caráter formal dos processos escolares, normatizados por instituições superiores oficiais e certificadores de titularidades. Difere da 
educação formal porque esta última possui uma legislação nacional que normatiza critérios e procedimentos específicos. [...] Destaca-se que a Educação Não Formal lida com outra lógica nas categorias espaço e tempo [...].

Nessa perspectiva, compreendemos que a ENF não substitui a educação formal nos processos de educação, mas pode ampliar as possibilidades das pessoas aprenderem, em contextos planejados, constituindo experiências, em diferentes espaços e tempos das atividades extracurriculares da escola. Por conseguinte, os educadores que atuam nesses contextos de ENF estão diante de sujeitos sociais "[...] com os quais necessitam desenvolver práticas educativas capazes de incorporar propostas/orientações pedagógicas, sem o que, segundo Gohn, tendemos a constituir um tipo de educador que pouco contribui para a transformação da sociedade" (ZUCCHETTI, 2012, p. 138). Se a ENF é espaço onde atuam educadores, configurando-se então em lócus de uma prática educativa com suas especificidades, é necessário que sejam ampliadas reflexões acerca da formação desses profissionais. Assim, buscamos por meio de uma pesquisa uma maior compreensão de um contexto de ENF - o Clube de Ciências - na perspectiva de um "lugar" de educação científica de estudantes e para a formação inicial docente.

Existem na América Latina mais de 500 Clubes de Ciências em funcionamento em escolas (TOMIO; HERMANN, 2019). Neste contexto, estudantes clubistas, com orientação de um professor, desenvolvem projetos investigativos a fim de elaborarem conhecimentos e ampliarem seus estilos de pensar, "[...] favorecendo para indagarem (se) e estabelecerem relações cada vez mais complexas no mundo e nas relações sustentáveis com o mundo e com os outros" (ROCHA; MELO; TOMIO, 2016, p. 332). Nesta modalidade de educação científica, no contraturno escolar, não há conteúdos programados previamente pelo professor, pois os temas de estudo surgem das necessidades, interesses e problemas identificados com os clubistas e, assim, os conhecimentos são construídos de modo colaborativo, por meio de investigações (PRÁ; TOMIO, 2014). Os Clubes de Ciências, com essas finalidades, contribuem para produção de experiências de ensino e de aprendizagem de conhecimentos científicos na escola, considerando as premissas da criatividade e da inovação em práticas colaborativas (TOMIO; HERMANN, 2019).

Um diferencial do Clube de Ciências como espaço para educação científica é que o desenvolvimento de suas atividades é sempre em uma dimensão que privilegia o trabalho cooperativo de um coletivo na escola. Nele, um estudante é o "clubista", ou seja, ocupa um lugar que se caracteriza pelas relações com outros clubistas, mediadas por saberes da ciência, constituindo o "clube". Nesta perspectiva, defendemos que o Clube de Ciências pode se constituir num contexto privilegiado para inclusão dos participantes em torno de um objetivo comum - aprender sobre ciência, convivendo com as diversidades na forma de relacionar-se com o mundo, no mundo (ROCHA et al., 2015).

Embora os Clubes de Ciências sejam espaços de educação não formal, funcionam em interfaces com a escola, são coordenados por professores e, como sugere Castro (2015, p. 1823), cada um desses contextos "têm seus próprios objetivos, conteúdos, referências teóricas, metodologias e embates internos nos seus campos". No entanto, quando consideramos suas contribuições "na perspectiva da Formação Integral, são todas igualmente necessárias e integradoras".

Com base nas dimensões apresentadas, compreendemos que um Clube de Ciências além de ser contexto de aprendizagens para estudantes da Educação Básica, pode também constituir-se em espaço para iniciação à docência de licenciandos, formando-se professores, para atuarem em contextos de ENF e/ou da educação formal, rompendo com a forma tradicional de organização dos tempos e espaços destinados convencionalmente para o ensino das Ciências da Natureza.

Diante disso, socializamos essa pesquisa que teve como pergunta orientadora: Que contribuições para formação de professores podem ser elucidadas de uma análise da produção científica desenvolvida pelo coletivo PIBID Ciências da Universidade Regional de Blumenau (FURB), acerca de suas práticas docentes em Clubes de Ciências?

O contexto investigado, de caráter bibliográfico, compreendeu toda produção científica escrita e divulgada por esse coletivo, 
entre os anos 2014 a 2017. Esse coletivo desenvolveu ações voltadas para a implantação e o desenvolvimento de Clubes de Ciências, com o apoio da Secretaria Municipal de Educação do Município de Blumenau, na vigência do edital CAPES/PIBID Portaria no 96 de 18/07/2013 ${ }^{1}$, em seis escolas públicas.

O subprojeto Ciências funcionou com os Clubes, tendo os professores de Ciências como coordenadores, que no PIBID assumiram também o papel de bolsistas supervisores, sendo "[...] coformadores dos futuros docentes e tornando protagonistas nos processos de formação inicial para o magistério" (BRASIL, 2013, p. 2). Cada Clube de Ciências contou, em média, com seis bolsistas de Iniciação à Docência (IDs), licenciandos do curso de Ciências Biológicas FURB. Na vigência do edital CAPES, participaram mais de 60 licenciandos, futuros professores de Ciências no PIBID. O subprojeto tinha ainda, na universidade, dois professores bolsistas coordenadores que atuaram na docência, pesquisa e extensão como foco em educação científica e formação docente. Nas escolas, cerca de 450 estudantes do ensino fundamental participaram do processo e se tornaram efetivos estudantes clubistas, além de se transformarem em multiplicadores, uma vez que desenvolviam seus projetos com os demais estudantes e as comunidades que as escolas pertencem. Os encontros nos Clubes de Ciências ocorriam uma vez por semana, no contraturno das aulas dos estudantes participantes.

Semanalmente, todos os bolsistas (IDs) se reuniam quatro horas na universidade para o planejamento e discussão de práticas educativas desenvolvidas na escola. Além disso, nesse tempo, eram estudados fundamentos acerca do

\footnotetext{
${ }^{1}$ Esse programa teve como objetivos :I - incentivar a formação de docentes em nível superior para a educação básica; II - contribuir para a valorização do magistério; III - elevar a qualidade da formação inicial de professores nos cursos de licenciatura, promovendo a integração entre educação superior e educação básica; IV - inserir os licenciandos no cotidiano de escolas da rede pública de educação, proporcionando-lhes oportunidades de criação e participação em experiências metodológicas, tecnológicas e práticas docentes de caráter inovador e interdisciplinar que busquem a superação de problemas identificados no processo de ensino aprendizagem; $\mathrm{V}$ - incentivar escolas públicas de educação básica, mobilizando seus professores como co-formadores dos futuros docentes e tornando-as protagonistas nos processos de formação inicial para o magistério; VI - contribuir para a articulação entre teoria e prática necessárias à formação dos docentes, elevando a qualidade das ações acadêmicas nos cursos de licenciatura; VII - contribuir para que os estudantes de licenciatura se insiram na cultura escolar do magistério, por meio da apropriação e da reflexão sobre instrumentos, saberes e peculiaridades do trabalho docente (CAPES, 2013, Art. 4ㅇ).
}

ensino de Ciências, da aprendizagem e de temas específicos que surgiam no transcorrer das atividades e que demandavam reflexão teórica.

Esse espaço de estudo, na universidade, foi ampliado para outros contextos, com a participação em eventos científicos e culturais, ampliando o repertório de experiências desse coletivo nas relações com outros interlocutores. Assim, na partilha das experiências docentes em Clubes de Ciências, bolsistas PIBID escreveram sobre suas práticas educativas, disseminando-as em uma significativa produção científica. Os produtos dessas participações em eventos científicos formam o contexto de análise nessa pesquisa em que objetivamos elucidar, a partir de uma análise da produção científica acerca de práticas docentes em Clubes de Ciências, desenvolvida pelo coletivo PIBID Subprojeto Ciências da Universidade Regional de Blumenau, contributos para a formação de professores em espaços de educação não formal.

Para isso, foram desenvolvidos os seguintes objetivos específicos: a) inventariar a produção científica desenvolvida pelo coletivo PIBID Subprojeto Ciências, divulgada em anais de eventos e periódicos científicos; b) caracterizar objetos de estudo, objetivos e referenciais teóricos organizados para investigação sobre práticas educativas desenvolvidas em/sobre Clubes de Ciências pelo coletivo, entre os anos 2013-2017; c) analisar, a produção científica acerca das práticas educativas em Clubes de Ciências, destacando as dimensões formativas, perspectivas e desafios para formação de professores em um espaço de educação não formal.

A socialização da pesquisa está organizada em mais três seções. Inicialmente descrevemos os procedimentos metodológicos. $\mathrm{Na}$ sequência, destacamos os resultados e respectivas interpretações e, por fim, apontamentos das considerações finais.

\section{DELINEAMENTO METODOLÓGICO}

A pesquisa se classifica como bibliográfica, pois consistiu na análise sistemática de uma produção científica. Segundo Santos (2000, p. 29, grifo nosso), a pesquisa bibliográfica é:

O conjunto de materiais escritos/gravados,

mecânica

ou eletronicamente, que contêm informações já 
elaboradas e publicadas por autores é uma bibliografia. São fontes bibliográficas os livros [...], as publicações periódicas (jornais, revistas, panfletos), páginas de web sites, relatórios de simpósios/seminários, anais de congresso etc.

Lima (2008) defende que, na pesquisa bibliográfica, os dados são coletados de fontes advindas de publicações que assumem a forma de livros, artigos publicados em periódicos (revistas e jornais), textos acadêmicos, entre outros e sua localização está orientada em função do problema de pesquisa. Diante disso, foram desenvolvidos os seguintes procedimentos metodológicos:

a) inventário da produção científica sobre Clubes de Ciências desenvolvida pelo coletivo a partir de busca das referências nos quatro relatórios anuais do PIBID (2014-2017). A partir das publicações referenciadas nos relatórios, buscaram-se os textos nos anais de eventos e periódicos científicos divulgados na internet e nos capítulos de livros impressos;

b) elaboração de um roteiro de leitura para geração de dados na análise da produção científica, identificando objetos de estudo, objetivos e referenciais teóricos organizados para investigação sobre práticas educativas desenvolvidas em/sobre Clubes de Ciências pelo coletivo PIBID Ciências (Apêndice A); c) organização dos dados gerados, na leitura da produção científica, em quadros para análise;

d) interpretações dos dados, considerando categorias de análise a priori, elaboradas com base em fundamentos teóricos. Nesta direção, recorremos a Arruda, Passos e Fregolente (2012) que organizaram Focos de Aprendizagem Docente (FAD), nos possibilitando uma análise da aprendizagem docente em diferentes contextos e situações de formação, como os Clubes de Ciências. Também Nóvoa (2017) sistematizou uma proposta de formação de professores, em cinco entradas construídas a partir do conceito de posição. Segundo o autor, esse termo possui uma riqueza de significados, podendo ser pensado como uma postura, uma condição, um estilo, um arranjo, uma opinião. Em nosso trabalho, articulamos essas dimensões propostas por Arruda, Passos e Fregolente (2012) e Nóvoa (2017) para estabelecer compreensões sobre a formação inicial docente.

\section{RESULTADOS E DISCUSSÃO}

Para apresentação dos resultados e discussão, partimos dos objetivos específicos:

\section{Inventário da produção científica}

O primeiro objetivo da pesquisa consistiu em inventariar a produção científica desenvolvida pelo coletivo PIBID Subprojeto Ciências FURB, divulgada em anais de eventos e periódicos científicos. A partir da leitura dos relatórios anuais do PIBID, sistematizou-se (quadro 1) a produção científica, considerando a ocorrência por anos e o gênero textual.

Quadro 1. Inventário da produção científica do PIBID Subprojeto Ciências FURB

\begin{tabular}{|c|c|c|c|c|c|c|}
\hline \multicolumn{2}{|c|}{ Gênero textual/Ano } & 2014 & 2015 & 2016 & 2017 & Total \\
\hline \multirow[t]{3}{*}{ Resumo } & MIPE* & 4 & 4 & 4 & 4 & 16 \\
\hline & MIPE (com Clubistas) & 4 & 4 & 4 & 4 & 16 \\
\hline & Outros eventos & 1 & 7 & 0 & 0 & 8 \\
\hline \multicolumn{2}{|c|}{ Resumo Expandido } & 0 & 0 & 3 & 4 & 7 \\
\hline \multicolumn{2}{|c|}{ Artigos científicos em eventos } & 2 & 4 & 2 & 0 & 8 \\
\hline \multicolumn{2}{|c|}{ Artigo em Revista PIBID } & 0 & 1 & 1 & 0 & 2 \\
\hline \multicolumn{2}{|c|}{ Capítulos de livros } & 0 & 0 & 0 & 8 & 8 \\
\hline \multicolumn{2}{|c|}{ TOTAL } & 11 & 21 & 15 & 20 & 65 \\
\hline
\end{tabular}

Fonte: Os autores.

Nota: *Mostra Interna de Pesquisa, Ensino, Extensão e Cultura

No quadro 2 é possível conferir os títulos e objetivos de cada publicação. Para cada uma foi convencionado um código de identificação, pelo qual, ao longo das análises, os trabalhos são citados: R: 
Resumo; RE: Resumo expandido; AE: Artigo de evento científico; AR: Artigo de revista e CL: Capítulo de livro. Cada código ainda recebe um número para sua identificação.

Quadro 2. Textos científicos divulgados pelo PIBID Subprojeto Ciências

\begin{tabular}{|c|c|c|c|}
\hline Ano & Código & Título & Objetivos \\
\hline \multirow[t]{11}{*}{2014} & $\begin{array}{l}\text { R1 } \\
\text { MIPE }\end{array}$ & $\begin{array}{l}\text { O desenvolvimento de um Clube } \\
\text { de Ciências na E.B.M. Machado de } \\
\text { Assis: espaços de formação de } \\
\text { estudantes e licenciados a partir } \\
\text { do subprojeto Biologia/PIBID }\end{array}$ & $\begin{array}{l}\text { Desenvolver o gosto pela ciência, } \\
\text { vinculando os conhecimentos científicos } \\
\text { ao cotidiano; realizar projetos de iniciação } \\
\text { científica; possibilitar um local de convívio } \\
\text { e conhecimento para discussão de temas } \\
\text { científicos; proporcionar ao estudante } \\
\text { uma experiência favorável para o } \\
\text { desenvolvimento do interesse pela } \\
\text { ciência. }\end{array}$ \\
\hline & $\begin{array}{l}\text { R2 } \\
\text { MIPE }\end{array}$ & $\begin{array}{l}\text { Desvendando as concepções sobre } \\
\text { os anfíbios a partir de atividades } \\
\text { de iniciação científica em um } \\
\text { Clube de Ciências. }\end{array}$ & $\begin{array}{l}\text { Elaborar conhecimentos científicos sobre } \\
\text { os anfíbios como animais importantes } \\
\text { para nossa biodiversidade. }\end{array}$ \\
\hline & $\begin{array}{l}\text { R3 } \\
\text { MIPE }\end{array}$ & $\begin{array}{l}\text { A investigação do contexto } \\
\text { socioambiental da comunidade } \\
\text { pelo Clube de Ciências Gatos-do- } \\
\text { mato. }\end{array}$ & $\begin{array}{l}\text { Investigar o contexto socioambiental da } \\
\text { comunidade em que a escola está inserida } \\
\text { e que impactos contribuem para as } \\
\text { enchentes. }\end{array}$ \\
\hline & $\begin{array}{l}\text { R4 } \\
\text { MIPE }\end{array}$ & $\begin{array}{l}\text { O Clube de Ciências girassol: uma } \\
\text { proposta de educação científica a } \\
\text { partir do subprojeto } \\
\text { PIBID/Biologia. }\end{array}$ & $\begin{array}{l}\text { Identificar e classificar espécies vegetais } \\
\text { existentes na escola. }\end{array}$ \\
\hline & $\begin{array}{l}\text { R5 } \\
\text { MIPE }\end{array}$ & $\begin{array}{l}\text { Propostas para incremento da } \\
\text { iniciação científica a partir do } \\
\text { Clube de Ciências. }\end{array}$ & $\begin{array}{l}\text { Promover a Educação científica dos } \\
\text { clubistas participantes a partir dos } \\
\text { projetos de pesquisa: Projeto Aquário e } \\
\text { Projeto Horta. }\end{array}$ \\
\hline & $\begin{array}{l}\text { R6 } \\
\text { MIPE }\end{array}$ & $\begin{array}{l}\text { Da observação das plantas à } \\
\text { construção do herbário na escola. }\end{array}$ & $\begin{array}{l}\text { Identificar e classificar espécies vegetais } \\
\text { existentes na escola. }\end{array}$ \\
\hline & $\begin{array}{l}\text { R7 } \\
\text { MIPE }\end{array}$ & $\begin{array}{l}\text { A aprendizagem docente no PIBID } \\
\text { Clube de Ciências. }\end{array}$ & $\begin{array}{l}\text { Analisar a formação dos PIBIDianos com } \\
\text { foco na sua aprendizagem docente. }\end{array}$ \\
\hline & $\begin{array}{l}\text { RE1 } \\
\text { C. } \\
\text { Ocean }\end{array}$ & $\begin{array}{l}\text { Os peixes invadiram a escola: } \\
\text { investigação da vida dos peixes }\end{array}$ & $\begin{array}{l}\text { Investigar um projeto sobre peixes com } \\
\text { clubistas, evidenciando relações entre } \\
\text { alfabetização científica e Educação } \\
\text { Ambiental. }\end{array}$ \\
\hline & $\begin{array}{l}\text { AE1 } \\
\text { Sinect }\end{array}$ & $\begin{array}{l}\text { Produções coletivas de mídias em } \\
\text { um Clube de Ciências. }\end{array}$ & $\begin{array}{l}\text { Desenvolver a escrita dos estudantes } \\
\text { propondo uma produção coletiva de } \\
\text { mídias no Clube de Ciências }\end{array}$ \\
\hline & $\begin{array}{l}\text { AE2 } \\
\text { Isatt }\end{array}$ & $\begin{array}{l}\text { Construindo e partilhando } \\
\text { conhecimentos em um Clube de } \\
\text { Ciências com foco no } \\
\text { desenvolvimento da autonomia e } \\
\text { da criticidade com apoio do PIBID }\end{array}$ & 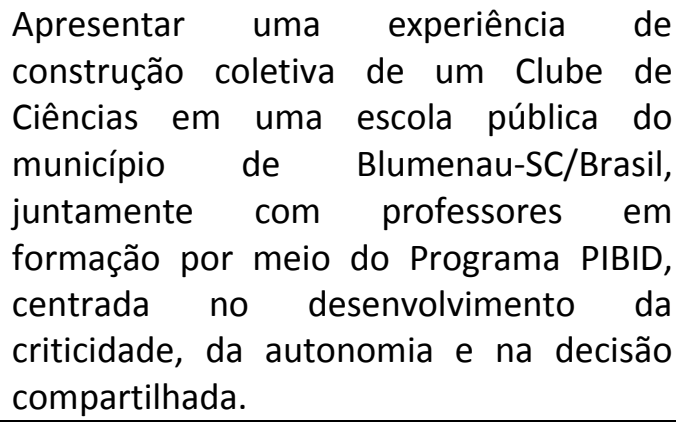 \\
\hline & $\begin{array}{l}\text { AE3 } \\
\text { Enalic }\end{array}$ & $\begin{array}{l}\text { Clube de Ciências como espaço na } \\
\text { escola de iniciação científica e } \\
\text { formação inicial de professores: }\end{array}$ & $\begin{array}{l}\text { Descrever percursos formativos de } \\
\text { licenciandos de Ciências Biológicas } \\
\text { participantes do PIBID Ciências. }\end{array}$ \\
\hline
\end{tabular}




\begin{tabular}{|c|c|c|c|}
\hline & & uma experiência no PIBID. & \\
\hline \multirow[t]{13}{*}{2015} & $\begin{array}{l}\text { R8 } \\
\text { MIPE }\end{array}$ & $\begin{array}{l}\text { A mata atlântica: quem conhece, } \\
\text { cuida! Um projeto desenvolvido } \\
\text { pelo Clube de Ciências gatos-do- } \\
\text { mato para a investigação do } \\
\text { ambiente ao redor da escola. }\end{array}$ & $\begin{array}{l}\text { Conhecer, compreender e proteger da } \\
\text { melhor maneira o ambiente ao nosso } \\
\text { redor. }\end{array}$ \\
\hline & $\begin{array}{l}\text { R9 } \\
\text { MIPE }\end{array}$ & $\begin{array}{l}\text { Da observação do céu à } \\
\text { classificação das nuvens. }\end{array}$ & $\begin{array}{l}\text { Identificar e classificar os diferentes tipos } \\
\text { de nuvens presentes, relacionando com o } \\
\text { tempo e o clima. }\end{array}$ \\
\hline & $\begin{array}{l}\text { R10 } \\
\text { MIPE }\end{array}$ & $\begin{array}{l}\text { O subprojeto PIBID Biologia e o } \\
\text { Clube de Ciências Fritz Müller: } \\
\text { espaço não formal de educação } \\
\text { científica e formação inicial de } \\
\text { professores de Ciências. }\end{array}$ & $\begin{array}{l}\text { Compreender as contribuições das } \\
\text { práticas educativas desenvolvidas no } \\
\text { Clube de Ciências Fritz Müller para } \\
\text { formação docente }\end{array}$ \\
\hline & $\begin{array}{l}\text { R11 } \\
\text { MIPE }\end{array}$ & $\begin{array}{l}\text { Ao PIBID e além: uma investigação } \\
\text { sobre foguetes em um Clube de } \\
\text { Ciências. }\end{array}$ & $\begin{array}{l}\text { Desenvolver o interesse pela ciência, } \\
\text { construindo seus conhecimentos através } \\
\text { de atividades práticas e teóricas na } \\
\text { construção de um foguete caseiro, sem } \\
\text { combustíveis explosivos. }\end{array}$ \\
\hline & $\begin{array}{l}\text { R12 } \\
\text { MIPE }\end{array}$ & $\begin{array}{l}\text { O ensino por investigação em um } \\
\text { Clube de Ciências: uma } \\
\text { experiência do PIBID na Formação } \\
\text { do professor de Ciências. }\end{array}$ & $\begin{array}{l}\text { Propiciar aos clubistas o estudo de temas } \\
\text { eleitos de acontecimentos do cotidiano } \\
\text { escolar, a partir da investigação para o } \\
\text { desenvolvimento da iniciação científica. }\end{array}$ \\
\hline & $\begin{array}{l}\text { R13 } \\
\text { MIPE }\end{array}$ & $\begin{array}{l}\text { Conhecendo os poríferos em um } \\
\text { Clube de Ciências a partir dos } \\
\text { estudos de Fritz Müller e cientistas } \\
\text { atuais. }\end{array}$ & $\begin{array}{l}\text { Identificar os passos de uma pesquisa } \\
\text { científica sobre poríferos, relacionando às } \\
\text { investigações de Fritz Müller e cientistas } \\
\text { atuais. }\end{array}$ \\
\hline & $\begin{array}{l}\text { R14 } \\
\text { MIPE }\end{array}$ & $\begin{array}{l}\text { Pesquisa sobre o bem estar de } \\
\text { cães e gatos domésticos no } \\
\text { entorno da EBM Professor João } \\
\text { Joaquim Fronza. }\end{array}$ & $\begin{array}{l}\text { Descobrir as condições de bem-estar de } \\
\text { cães e gatos nos arredores da escola, e } \\
\text { conscientizar as pessoas sobre o cuidado } \\
\text { com os mesmos. }\end{array}$ \\
\hline & $\begin{array}{l}\text { R15 } \\
\text { MIPE }\end{array}$ & $\begin{array}{l}\text { Projeto Por Quê? Atividade } \\
\text { investigação no Clube de Ciências. }\end{array}$ & $\begin{array}{l}\text { Apresentar o projeto Por quê? } \mathrm{E} \\
\text { sistematizar esta proposta didático- } \\
\text { pedagógica para que possa servir de } \\
\text { auxílio para outros estudantes ou } \\
\text { professores de ciências. }\end{array}$ \\
\hline & R16 & $\begin{array}{l}\text { Resultados preliminares do } \\
\text { projeto milleriano: um projeto de } \\
\text { iniciação científica realizado em } \\
\text { um Clube de Ciências. }\end{array}$ & $\begin{array}{l}\text { (sem acesso ao texto) XI Seminário das } \\
\text { Licenciaturas e VI Seminário PIBID - }\end{array}$ \\
\hline & R17 & $\begin{array}{l}\text { Formação docente em um Clube } \\
\text { de Ciências por meio do ensino } \\
\text { com investigação. }\end{array}$ & $\begin{array}{l}\text { (sem acesso ao texto) XI Seminário das } \\
\text { Licenciaturas e VI Seminário PIBID - }\end{array}$ \\
\hline & R18 & $\begin{array}{l}\text { Projeto A cara do Lixo: } \\
\text { investigando a separação do lixo } \\
\text { em um Clube de Ciências. }\end{array}$ & $\begin{array}{l}\text { (sem acesso ao texto) XI Seminário das } \\
\text { Licenciaturas e VI Seminário PIBID - }\end{array}$ \\
\hline & $\begin{array}{l}\text { R19 } \\
\text { Cong. } \\
\text { Mastol }\end{array}$ & $\begin{array}{l}\text { Projeto Felino: um trabalho de } \\
\text { aprendizagem e conscientização } \\
\text { orientado por bolsistas PIBID em } \\
\text { um Clube de Ciências }\end{array}$ & Diferenciar felinos da Mata Atlântica. \\
\hline & $\begin{array}{l}\text { R20 } \\
\text { Sem. } \\
\text { PIBID }\end{array}$ & $\begin{array}{l}\text { Abra a sua mente. O que você } \\
\text { "vê"? }\end{array}$ & $\begin{array}{l}\text { Relatar a experiência que estamos } \\
\text { adquirindo com a participação de um } \\
\text { estudante com deficiência visual no Clube }\end{array}$ \\
\hline
\end{tabular}




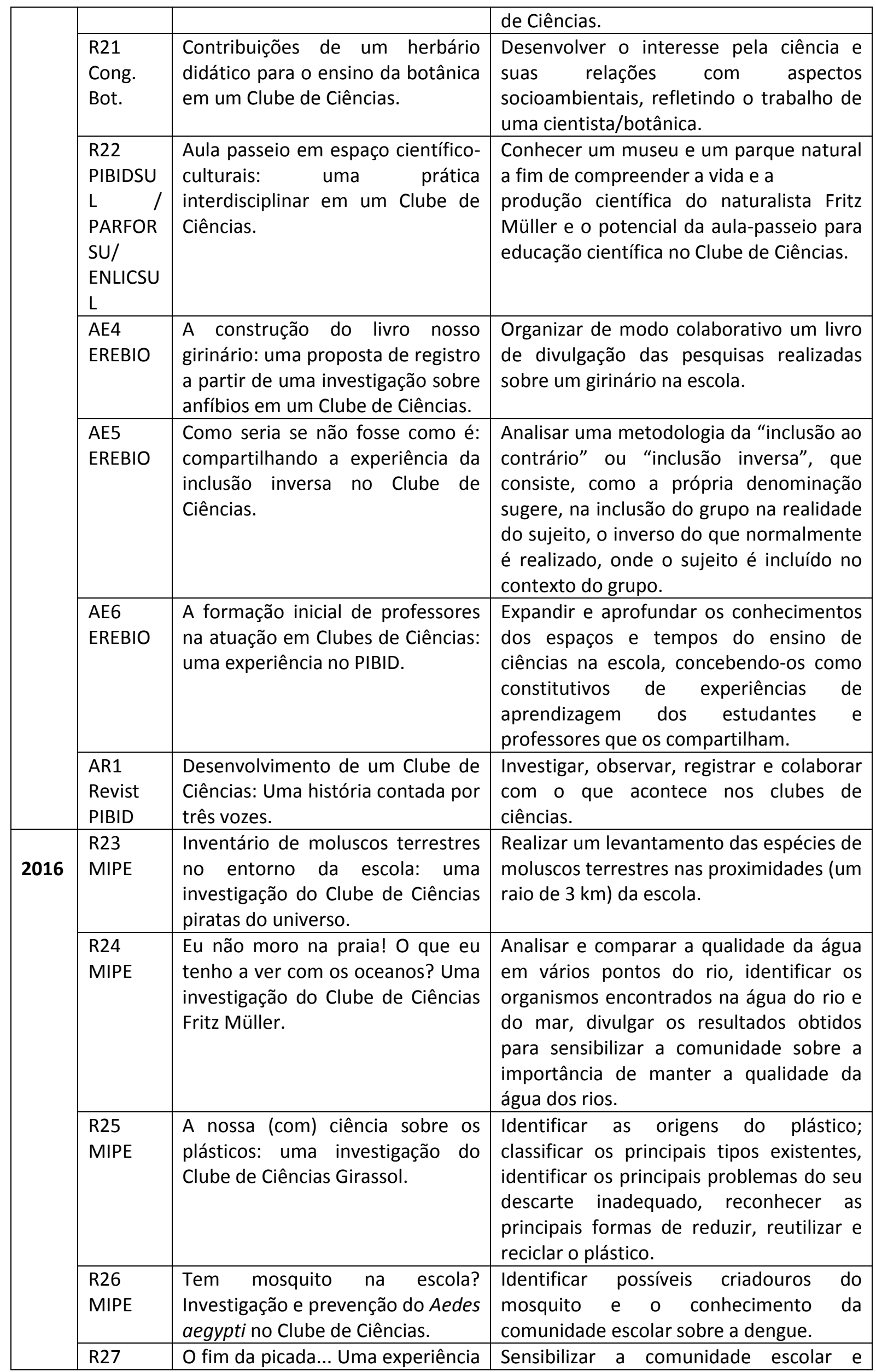




\begin{tabular}{|c|c|c|}
\hline MIPE & docente no Clube de Ciências. & $\begin{array}{l}\text { território da presença do Aedes aegypti e } \\
\text { formas de combate de sua proliferação no } \\
\text { ambiente. }\end{array}$ \\
\hline $\begin{array}{l}\text { R28 } \\
\text { MIPE }\end{array}$ & $\begin{array}{l}\text { A construção de um espaço de } \\
\text { aprendizagem em um Clube de } \\
\text { Ciências e na docência pelo PIBID. }\end{array}$ & $\begin{array}{l}\text { Planejar e construir de forma colaborativa } \\
\text { a sala do Clube de forma a constitui-la } \\
\text { como um espaço cooperativo, criativo e } \\
\text { de protagonismo para aprender a ciência } \\
\text { nas relações consigo e com os outros. }\end{array}$ \\
\hline $\begin{array}{l}\text { R29 } \\
\text { MIPE }\end{array}$ & $\begin{array}{l}\text { Escrever e aprender ciência em um } \\
\text { Clube de Ciências: experiências } \\
\text { docentes no PIBID com letramento } \\
\text { científico. }\end{array}$ & $\begin{array}{l}\text { Desenvolver situações de escrita na } \\
\text { direção do desenvolvimento } \\
\text { letramento científico dos clubistas. }\end{array}$ \\
\hline $\begin{array}{l}\text { R30 } \\
\text { MIPE }\end{array}$ & $\begin{array}{l}\text { Laboratório e saídas de campo: } \\
\text { espaços de docência do PIBID e de } \\
\text { aprender em um Clube de } \\
\text { Ciências. }\end{array}$ & $\begin{array}{l}\text { Desenvolver atividades com os clubistas } \\
\text { que contribuíssem para vivenciarem } \\
\text { processos de pesquisa científica sobre e } \\
\text { em ambientes aquáticos, a partir de } \\
\text { práticas investigativas no laboratório e em } \\
\text { saídas de campo. O foco do trabalho } \\
\text { colaborativo de investigação foi analisar a } \\
\text { qualidade da água em vários pontos de } \\
\text { ribeirões e do Rio Itajaí-Açú em } \\
\text { Blumenau. }\end{array}$ \\
\hline $\begin{array}{l}\text { R30 } \\
\text { ENALIC }\end{array}$ & $\begin{array}{l}\text { O que acontece quando existem } \\
\text { abelhas na escola? Práticas } \\
\text { investigativas e de docência em } \\
\text { um Clube de Ciências com o PIBID. }\end{array}$ & $\begin{array}{l}\text { Elucidar o processo de desenvolvimento } \\
\text { de uma prática investigativa sobre as } \\
\text { abelhas na escola com um Clube de } \\
\text { Ciências, evidenciando nossas } \\
\text { compreensões da prática docente neste } \\
\text { contexto. }\end{array}$ \\
\hline $\begin{array}{l}\text { R31 } \\
\text { ENALIC }\end{array}$ & $\begin{array}{l}\text { Circulando saberes, pela escrita, } \\
\text { em um Clube de Ciências: práticas } \\
\text { docentes no PIBID para o } \\
\text { letramento científico. }\end{array}$ & $\begin{array}{l}\text { Desenvolver situações de escrita na } \\
\text { direção do desenvolvimento do } \\
\text { letramento científico dos clubistas de } \\
\text { equipe. }\end{array}$ \\
\hline $\begin{array}{l}\text { R32 } \\
\text { ENALIC }\end{array}$ & $\begin{array}{l}\text { Experiências docentes no PIBID na } \\
\text { construção de espaços (físicos) } \\
\text { para aprender em Clubes de } \\
\text { Ciências. }\end{array}$ & $\begin{array}{l}\text { Desenvolver experiências docentes } \\
\text { articuladas a revitalização de espaços } \\
\text { físicos de aprender Ciências em duas } \\
\text { escolas públicas de Blumenau/SC. Com o } \\
\text { objetivo de elucidar os processos de } \\
\text { construções coletivas dos espaços (físicos) } \\
\text { de aprender em Clube de Ciências. }\end{array}$ \\
\hline $\begin{array}{l}\text { AE7 } \\
\text { SINECT }\end{array}$ & $\begin{array}{l}\text { Construção coletiva do espaço } \\
\text { (físico) de um Clube de Ciências. }\end{array}$ & $\begin{array}{l}\text { Clubes de Ciências têm o objetivo de } \\
\text { incrementar o interesse pela ciência que é } \\
\text { vista como um processo em contínua } \\
\text { construção. Os Clubes de Ciências } \\
\text { objetivam ainda incentivar a curiosidade, } \\
\text { a "tomada de decisão", o } \\
\text { desenvolvimento de pesquisas do } \\
\text { interesse dos clubistas para que o ensino } \\
\text { de ciências seja um processo construtivo } \\
\text { de constante participação dos estudantes. }\end{array}$ \\
\hline $\begin{array}{l}\text { AE8 } \\
\text { COLBED } \\
\text { UCA }\end{array}$ & $\begin{array}{l}\text { A construção coletiva de um } \\
\text { "espaço" de aprendizagem em um } \\
\text { Clube de Ciências. }\end{array}$ & $\begin{array}{l}\text { Elucidar o processo de construção coletiva } \\
\text { do espaço (físico) de aprender de um } \\
\text { Clube de Ciências, evidenciando as } \\
\text { percepções dos estudantes/clubistas }\end{array}$ \\
\hline
\end{tabular}




\begin{tabular}{|c|c|c|c|}
\hline & & & envolvidos. \\
\hline \multirow[t]{11}{*}{2017} & $\begin{array}{l}\text { R33 } \\
\text { MIPE }\end{array}$ & $\begin{array}{l}\text { O bosque escolar como espaço } \\
\text { para conhecimento da } \\
\text { biodiversidade pelo coletivo da } \\
\text { nossa escola: um projeto } \\
\text { investigativo do Clube de Ciências } \\
\text { gatos-do-mato. }\end{array}$ & $\begin{array}{l}\text { Identificar elementos da biodiversidade } \\
\text { do bosque da escola a fim de organizar } \\
\text { uma trilha interpretativa. }\end{array}$ \\
\hline & $\begin{array}{l}\text { R34 } \\
\text { MIPE }\end{array}$ & $\begin{array}{l}\text { Diagnósticos para o planejamento } \\
\text { de projetos investigativos: uma } \\
\text { experiência de docência no PIBID } \\
\text { em clubes de ciências. }\end{array}$ & $\begin{array}{l}\text { Propor estratégias para diagnóstico de } \\
\text { conceitos acerca do tema biodiversidade } \\
\text { na escola. }\end{array}$ \\
\hline & $\begin{array}{l}\text { R35 } \\
\text { MIPE }\end{array}$ & $\begin{array}{l}\text { A utilização do espaço de um } \\
\text { Clube de Ciências através do } \\
\text { PIBID-biologia como contribuição } \\
\text { para a formação docente. }\end{array}$ & $\begin{array}{l}\text { Estimular atitudes sustentáveis, por meio } \\
\text { de saídas a campo, experimentos e o } \\
\text { tratamento de temas ambientais de } \\
\text { forma lúdica e interações com o projeto } \\
\text { "Cidades sustentáveis" }\end{array}$ \\
\hline & $\begin{array}{l}\text { R36 } \\
\text { MIPE }\end{array}$ & \begin{tabular}{lcr} 
Pipocando & \multicolumn{2}{c}{ conhecimentos: } \\
experiências docentes de & dos \\
alfabetização científica em um \\
Clube de Ciências com o PIBID.
\end{tabular} & $\begin{array}{l}\text { Desenvolver práticas investigativas na } \\
\text { direção da alfabetização científica dos } \\
\text { clubistas, a partir do estudo do milho. }\end{array}$ \\
\hline & $\begin{array}{l}\text { R37 } \\
\text { MIPE }\end{array}$ & $\begin{array}{l}\text { A ciência do milho: um projeto } \\
\text { investigativo do Clube de Ciências. }\end{array}$ & $\begin{array}{l}\text { Identificar as características da planta do } \\
\text { milho; conhecer sua origem; diferenciar } \\
\text { seus tipos e investigar as diferentes } \\
\text { formas de estourá-lo. }\end{array}$ \\
\hline & $\begin{array}{l}\text { R38 } \\
\text { MIPE }\end{array}$ & $\begin{array}{l}\text { Como seria uma cidade que não } \\
\text { gerasse resíduos? Uma } \\
\text { investigação do Clube de Ciências } \\
\text { Fritz Muller e PIBID }\end{array}$ & $\begin{array}{l}\text { Identificar elementos da biodiversidade } \\
\text { do bosque da escola a fim de organizar } \\
\text { uma trilha interpretativa. }\end{array}$ \\
\hline & $\begin{array}{l}\text { R39 } \\
\text { MIPE }\end{array}$ & $\begin{array}{l}\text { Um gambá na escola! Um projeto } \\
\text { investigativo do Clube de Ciências } \\
\text { girassol }\end{array}$ & $\begin{array}{l}\text { Explicar o modo de vida dos gambás; } \\
\text { identificar e diferenciar espécies nativas } \\
\text { de gambás da região sul e levantar os } \\
\text { saberes dos moradores da comunidade } \\
\text { sobre os gambás. }\end{array}$ \\
\hline & $\begin{array}{l}\text { R40 } \\
\text { MIPE }\end{array}$ & $\begin{array}{l}\text { O bosque escolar como espaço } \\
\text { para conhecimento da } \\
\text { biodiversidade pelo coletivo da } \\
\text { nossa escola: um projeto } \\
\text { investigativo do Clube de Ciências } \\
\text { gatos-do-mato }\end{array}$ & $\begin{array}{l}\text { Identificar elementos da biodiversidade } \\
\text { do bosque da escola a fim de organizar } \\
\text { uma trilha interpretativa. }\end{array}$ \\
\hline & $\begin{array}{l}\text { RE2 } \\
\text { ENALIC }\end{array}$ & $\begin{array}{l}\text { Clube de Ciências como um espaço } \\
\text { de docência: reflexões a partir de } \\
\text { uma análise da produção científica } \\
\text { do PIBID ciências. }\end{array}$ & $\begin{array}{l}\text { Compreender os contributos para a } \\
\text { formação de professores acerca de suas } \\
\text { práticas docentes em clubes de ciências a } \\
\text { partir de uma análise da produção } \\
\text { científica divulgada na MIPE desenvolvida } \\
\text { pelo coletivo PIBID ciências. }\end{array}$ \\
\hline & $\begin{array}{l}\text { RE3 } \\
\text { Fórum } \\
\text { Brasil. } \\
\text { EA }\end{array}$ & $\begin{array}{l}\text { Fotografando habitats na escola: } \\
\text { uma experiência de educação } \\
\text { ambiental com um Clube de } \\
\text { Ciências e o PIBID. }\end{array}$ & $\begin{array}{l}\text { Sensibilizar os clubistas para um observar } \\
\text { crítico aos habitats da escola a partir do } \\
\text { desenvolvimento de uma gincana } \\
\text { fotográfica. }\end{array}$ \\
\hline & $\begin{array}{l}\text { RE4 } \\
\text { Fórum } \\
\text { Brasil. } \\
\text { EA }\end{array}$ & $\begin{array}{l}\text { Projeto oceano: uma prática de } \\
\text { educação ambiental do PIBID em } \\
\text { um Clube de Ciências. }\end{array}$ & $\begin{array}{l}\text { Sensibilizar os clubistas quanto às ações } \\
\text { locais que impactam o ambiente global. }\end{array}$ \\
\hline
\end{tabular}




\begin{tabular}{|c|c|c|}
\hline $\begin{array}{l}\text { RE5 } \\
\text { Fórum } \\
\text { Brasil. } \\
\text { EA }\end{array}$ & $\begin{array}{l}\text { Um gambá na } \\
\text { experiela...Uma } \\
\text { Ambiental em um Clube de } \\
\text { Ciências com o PIBID }\end{array}$ & $\begin{array}{l}\text { Desenvolver práticas de Educação } \\
\text { ambiental a partir de um encontro com } \\
\text { um gambá na escola }\end{array}$ \\
\hline CL1 & $\begin{array}{l}\text { caderno e outros gêneros } \\
\text { discursivos.... Escrever no Clube de } \\
\text { Ciências }\end{array}$ & $\begin{array}{l}\text { Divulgar práticas educativas de incentivo à } \\
\text { escrita em um Clube de Ciências }\end{array}$ \\
\hline CL2 & $\begin{array}{llr}\text { Práticas educativas em um } & \text { Clube } \\
\text { de Ciências para } & \text { o } \\
\text { desenvolvimento da } & & \\
\text { autonomia } & & \end{array}$ & $\begin{array}{l}\text { Promover o Clube de Ciências como } \\
\text { contexto de desenvolvimento da } \\
\text { autonomia do estudante da Educação } \\
\text { Básica }\end{array}$ \\
\hline CL3 & $\begin{array}{l}\text { Clube de Ciências Aventureiros do } \\
\text { Conhecimento: A vivência da } \\
\text { inclusão }\end{array}$ & $\begin{array}{l}\text { Socializar práticas educativas no Clube de } \\
\text { Ciências com foco na inclusão }\end{array}$ \\
\hline CL4 & $\begin{array}{l}\text { Clube de Ciências Girassol: A } \\
\text { Escola como espaço de } \\
\text { investigação }\end{array}$ & $\begin{array}{l}\text { Socializar práticas educativas no Clube de } \\
\text { Ciências com foco na investigação }\end{array}$ \\
\hline CL5 & $\begin{array}{l}\text { Clube de Ciências Gatos do Mato: } \\
\text { A investigação do contexto } \\
\text { socioambiental da comunidade }\end{array}$ & $\begin{array}{l}\text { Socializar práticas educativas no Clube de } \\
\text { Ciências com foco no estudo do contexto } \\
\text { socioambiental da comunidade }\end{array}$ \\
\hline CL6 & $\begin{array}{l}\text { Clube de Ciências Fritz Müller: } \\
\text { Projeto Por quê? Como proposta } \\
\text { de atividade } \\
\text { investigativa }\end{array}$ & $\begin{array}{l}\text { Socializar práticas educativas no Clube de } \\
\text { Ciências com foco na experimentação }\end{array}$ \\
\hline CL7 & $\begin{array}{l}\text { Clube de Ciências Gataca: Inserção } \\
\text { em uma Escola Sustentável }\end{array}$ & $\begin{array}{l}\text { Socializar práticas educativas no Clube de } \\
\text { Ciências com foco em um projeto de } \\
\text { escola sustentável }\end{array}$ \\
\hline CL8 & $\begin{array}{l}\text { Clube de Ciências como contexto } \\
\text { (do PIBID) de formação docente }\end{array}$ & $\begin{array}{l}\text { Socializar o subprojeto PIBID Ciências em } \\
\text { suas atividades de formação docente }\end{array}$ \\
\hline
\end{tabular}

Fonte: Os autores.

Com base nos quadros 1 e 2 podemos evidenciar que entre os anos 2014 a 2017 o coletivo PIBID Subprojeto Ciências FURB publicou 65 trabalhos científicos. Dentre eles, foram 31 resumos na MIPE (Mostra Interna de Pesquisa, Ensino, Extensão e Cultura), um evento local, que acontece todos os anos na Universidade a fim de divulgar para comunidade interna e externa as atividades de pesquisa, ensino, extensão e cultura que desenvolve. No quadro 1 é possível observar duas linhas de trabalhos da MIPE - essa separação foi organizada para evidenciar dois grupos de trabalhos socializados, o primeiro escrito pelos bolsistas de Iniciação à Docência em conjunto com Professores Supervisores e Coordenadores que consiste no relato de práticas investigativas, no "lugar" de professores, refletindo acerca de atividades docentes realizadas nos contextos dos Clubes de Ciências das escolas parceiras. O segundo grupo, socializa investigações dos clubistas, estudantes da educação básica, que escreveram os resumos dos seus Clubes com a mediação dos bolsistas PIBID. Assim, na MIPE acontecia concomitantemente a socialização das produções (em banners e nos anais) dos IDs e dos clubistas, por eles mediados. Como afirma Nóvoa (2009, p. 42-43):

As escolas são lugares da relação e da comunicação. Mas as escolas comunicam mal com o exterior. Os professores explicam mal o seu trabalho. [...]. E, sobretudo, há uma ausência da voz dos professores nos debates públicos. É necessário aprender a comunicar com o público, a ter uma voz pública, a conquistar a sociedade para o trabalho educativo comunicar para fora da escola. 
Assim, interpreta-se que essa divulgação local das práticas educativas no "lugar" de docentes potencializa uma cultura na universidade e na comunidade atribuindo maior visibilidade à licenciatura e, por extensão, ao trabalho do Professor.

Além disso, a divulgação dos trabalhos dos Clubes de Ciências, a partir de práticas colaborativas de escrita entre clubistas/estudantes da educação básica e IDs/futuros professores pode contribuir para a formação de docentes com a compreensão de que escrever para aprender Ciências não se faz pela repetição e cópia de textos, mas pela possibilidade de estudantes entenderem e participarem de uma cultura científica, praticando algumas de suas normas e, principalmente, utilizando diversas linguagens das ciências, sofisticando as suas formas de conhecer/produzir discursos a fim de compreenderem e enfrentarem os desafios de suas realidades, de modo cada vez mais complexo.

Outro conjunto de resumos refere-se às participações em nove eventos, sendo três deles nacionais não relacionados à Educação, como IV Congresso Brasileiro de Oceanografia - Itajaí (RE 01); VII Congresso Brasileiro de Mastologia/João Pessoa (R19) e 66으 Congresso Brasileiro de Botânica/Santos (R21). Nesses eventos, os bolsistas PIBID compartilharam suas práticas educativas entre outros campos de estudo da Biologia, ampliando espaços sociais de discussão em educação científica e educação ambiental com outros coletivos, por conseguinte, colaborando para sua formação docente.

Outros seis resumos foram em eventos específicos do PIBID, como o ENALIC - Encontro Nacional das Licenciaturas e Seminário Nacional do PIBID (R20, 22, 30, 31, 32) promovendo a circulação de trabalhos acerca de suas práticas educativas com seus pares de outras instituições. Interpreta-se que essa interlocução, por escrito e nas apresentações orais, colabora para "[...]consolidar as bases de uma formação que tenha como referência lógicas de acompanhamento, de formação-em-situação, de análise da prática e de integração na cultura profissional docente" (NÓVOA, 2009, p. 38).

Além desses, destacam-se ainda sete resumos expandidos, mais detalhados, em eventos nacionais como, por exemplo, o Fórum Brasileiro de Educação Ambiental/Itajaí, revelando interfaces de práticas educativas de educação científica com a educação ambiental.

No quadro 1 ainda é possível observar a ocorrência de oito artigos científicos socializados em eventos nacionais e em seus anais, como em duas edições do Simpósio Nacional de Ensino de Ciência e Tecnologia - SINECT (AE1; AE7); no Colóquio Luso-Brasileiro de Educação COLBEDUCA (AE8); no ENALIC (AE3) também um em evento internacional no Congresso ISATT, na Universidade de Minho / Portugal (AE2). Os demais são resultados de publicações em edições do Encontro Regional de Ensino de Biologia EREBIO Sul (AE 4, 5, 6).

Cabe destacar dois artigos apresentados em revistas locais, do contexto PIBID FURB, escritos por iniciativas de dois IDS (AR1 e 2) que apresentam reflexões acerca de seus percursos formativos, evidenciando as suas experiências docentes no PIBID nas mesmas escolas em que estudaram quando crianças.

Por fim, destacam-se oito capítulos escritos para o livro "Clubes de Ciências: Contextos de Educação Científica, Pesquisa, Extensão e Docência no PIBID". A obra, em fase de publicação, reúne um conjunto de estudos de um coletivo formado por docentes da universidade (especialmente da Universidade Regional de Blumenau) e de escolas públicas; acadêmicos de cursos de licenciaturas, mestrandos da pós-graduação em Educação e Ensino de Ciências Naturais, bolsistas do Programa Institucional de Bolsas de Iniciação à Docência e estudantes da Educação Básica que compartilharam experiências de aprender Ciências, formar-se professor e pesquisador em contextos de Clubes de Ciências.

Observou-se que $70 \%$ dos trabalhos escritos e socializados pelo coletivo PIBID Subprojeto Ciências consistiu em resumos. Embora trate-se de um gênero acadêmico de menor extensão (geralmente até 500 palavras), infere-se que este permite que o licenciando exercite a habilidade de síntese, para relatar em poucas palavras a sua prática educativa, evidenciando os aspectos mais relevantes para o entendimento público. Os resumos analisados permitiram identificar aspectos privilegiados pelo coletivo para o desenvolvimento da docência e educação científica nos Clubes de Ciências, que serão discutidos na próxima seção.

Os demais trabalhos (30\%) da produção científica apresentam maior sistematização, com evidências de reflexão teórica acerca das práticas 
educativas relatadas. Constatou-se que a socialização dos trabalhos foi em eventos da área de Educação e, especificamente, da área de Ensino de Ciências da Natureza, possibilitando circular nesses lugares práticas educativas e de formação docente no contexto da Educação Não Formal (ENF) e suas interfaces com a Educação Formal. Nesta relação, concorda-se com Castro (2015, p. 183) de que são tipologias com finalidades distintas, por isso, "[...] é preciso que levem em consideração as suas especificidades, mas que estejam associadas em um objetivo geral, comum a todos os processos educativos, isto é, o de promover uma formação humana completa, voltada para o autogoverno, a emancipação e a transformação social.". Diante disso, qual a contribuição de formar-se professor em um contexto de ENF, como os Clubes de Ciências? Para essa resposta, na próxima seção serão destacados aspectos da análise dos textos da produção científica inventariada.

\section{FOCOS DE APRENDIZAGEM DOCENTE PARA ANÁLISE DA PRODUÇÃO CIENTÍFICA}

Para cumprir o segundo objetivo específico de caracterizar objetos de estudo, objetivos e referenciais teóricos organizados para investigação sobre práticas educativas desenvolvidas em/sobre Clubes de Ciências pelo coletivo PIBID Ciências FURB, entre os anos 20132017, realizou-se a leitura de todos os textos inventariados (Quadro 2) com um roteiro de leitura (Apêndice A) e os dados gerados foram sistematizados em quadros, de acordo com a ocorrência. No entanto, dada extensão dos dados elaborados, optou-se em socializar nesse artigo apenas os resultados. Esses foram interpretados, considerando os Focos de Aprendizagem Docente (FAD), propostos por Arruda, Passos e Fregolente (2012). Segundo esses autores, os FAD possibilitam uma análise da aprendizagem docente em diferentes contextos e situações de formação, como:

(i) Na formação inicial, nos cursos de licenciatura; no estágio supervisionado. (ii) $\mathrm{Na}$ formação em serviço, continuada; nos cursos de capacitação de professores.

(iii) Em programas especiais de formação de professores como 0 Programa Institucional de
Bolsas de Iniciação à Docência (PIBID).

(iv) Em situações informais do dia a dia, na família, no trabalho.

(v) Em ambientes de educação informal [não formal] planejados, como os museus, centros de ciências etc. (ARRUDA; PASSOS; FREGOLENTE; 2012, p. 33, grifos nossos).

Nesta perspectiva, a opção pelos FAD como categorias de análise dos dados, definidas $a$ priori, justifica-se pelo fato de que eles permitem observar relações das especificidades de um contexto educacional, como os Clubes de Ciências, com a aprendizagem da docência. Os FAD são organizados de acordo com cinco dimensões da formação docente, mas que são interdependentes, de forma que o desenvolvimento em uma delas contribuiria para o desenvolvimento de todas as outras. Com base nos autores, podemos citar os cinco focos: conhecimento prático da docência; reflexão sobre a docência; comunidade docente; identidade docente $e$ interesse pela docência. Em nossas análises, articulamos os FADs com as cinco posições sistematizadas por Nóvoa (2017) para que a formação docente seja pensada disposição pessoal, interposição profissional, composição pedagógica, recomposição investigativa $e$ exposição pública.

$\mathrm{Na}$ sequência abordamos nossas categorias de análise:

\section{CONHECIMENTO PRÁTICO DA DOCÊNCIA}

Segundo Arruda, Passos e Fregolente (2012, p. 32) "a partir do conhecimento na ação e com base na reflexão na ação, o estudante desenvolve o conhecimento de casos, um repertório de experiências didáticas e pedagógicas que orientam a sua prática cotidiana in actu". Nessa direção, observamos que, em comum, todas as produções científicas são escritas no formato de relatos de experiência, ou seja, são narradas práticas educativas desenvolvidas pela docência no contexto de Clubes de Ciências. Assim, geralmente os textos apresentam os Clubes de Ciências e seus objetivos, relatam uma sequência de ações realizadas com os clubistas e fazem interpretações com leituras acerca do tema relatado, por fim evidenciam contribuições da 
experiência para educação científica dos clubistas e para formação docente dos licenciandos. Seus textos nos permitem interpretar percursos formativos na direção que Imbernón (2011, p. 4142) chama a atenção: "[...] o eixo fundamental do currículo de formação do professor é o desenvolvimento da capacidade de refletir sobre a própria prática docente, com o objetivo de aprender a interpretar, compreender e refletir sobre a realidade social e à docência".

Assim, dentre as práticas educativas refletidas e socializadas pelo coletivo PIBID, observamos diferentes possibilidades de planejar e conduzir atividades com foco na educação científica dos estudantes clubistas (crianças e adolescentes entre a faixa de 10 a 14 anos). Nesse repertório de práticas, destacam-se as atividades diagnósticas para leitura socioambiental do contexto escolar e da comunidade a fim de identificar com os clubistas possíveis temas de investigação para os estudos futuros. (Exemplos: R3,6,8, 14...RE3, CL5...). Deste modo, são criados diferentes roteiros, envolvendo a geração de informações com registros escritos, desenhos e o emprego de tecnologias digitais (fotos, filmagens, etc.), possibilitando o desenvolvimento de propostas de ensino, partindo de contextos locais e envolvendo os estudantes como protagonistas do planejamento. Também são desenvolvidas atividades diagnósticas para leitura das concepções dos clubistas sobre a ciência, o fazer ciência e cientista (R21, R23, AE3...). Com isso, os IDs obtêm elementos para uma análise didática, considerando as hipóteses dos estudantes sobre a natureza da ciência, bem como suas próprias concepções.

Constatamos o desenvolvimento de uma variedade de práticas educativas para educação científica nos Clubes de Ciências: aula passeio (R22, R30); experimentação (R11, R25); investigações em campo (R23, R24, R30); enquetes com a comunidade (R18, R26); letramentos (R29, AE4, CL1); tecnologias digitais (AE1, RE3) que foram interpretadas nos textos a partir de suas contribuições para o trabalho colaborativo e com respeito às diversidades; investigação; desenvolvimento da autonomia; envolvimento de diferentes sujeitos das comunidades; interlocução com pesquisadores da universidade e de outros contextos profissionais; estudo em laboratórios e outros espaços da universidade; visitas em outros contextos para busca de informações; práticas interdisciplinares; atividades de escrita próximas à cultura científica, ampliação do repertório cultural; atividades de sensibilização socioambiental, e atividades que incentivem a experiência estética. Destacamos alguns excertos representativos dessas contribuições a partir dos textos:

Permitiu refletir que a cooperação para a formação do ambiente pode ser valiosa para o aprendizado, pois promove a interação $e$ a apropriação do que foi construído, dando importância a cada detalhe, ao final do trabalho pudemos perceber que todo esse processo provocou transformações pedagógicas, políticas, sociais e culturais. Entre as transformações, merece destaque o estreitamento de laços entre professores em formação e os clubistas, criando relações horizontais, onde a liderança é partilhada por todos os membros do grupo, vindo ao encontro da essência de um espaço de promoção da cultura científica, como o Clube de Ciências Piratas do Universo (R28).

Podemos concluir que o caderno de relatos tem contribuído aos estudantes em seu letramento científico e a nós, bolsistas, a compreensão na docência de que escrever para aprender ciências não se faz pela repetição e cópia de textos, mas pela possibilidade de nossos estudantes entenderem e participarem de uma cultura científica, praticando algumas de suas normas $e$ principalmente as diversas linguagens das ciências (R29).

Esta experiência possibilitou tanto aos clubistas quanto aos bolsistas do PIBID, futuros professores de Ciências, a oportunidade de desenvolverem uma prática de educação científica considerando o diagnóstico como ponto de partida para o planejamento interdisciplinar de projetos investigativos que contribuam para $o$ desenvolvimento de conceitos científicos, bem como desenvolverem habilidades e atitudes de modo criativo, colaborativo e sensível às nossas relações socioambientais com os outros, as outras espécies, no e com o mundo, na escola (R40).

Ainda, no processo de organização dos Clubes de Ciências nas escolas, observamos na produção científica o tema espaço físico para aprender (R28, 30, 35, AE8) e para além das edificações, contemplando os espaços naturais 
(R32, 40, CL7). Neste sentido, podemos notar pela leitura dos trabalhos que os IDs, juntamente com os clubistas, organizaram e efetivaram 0 processo de revitalização de laboratórios, adaptando-o, também, às necessidades do Clube de Ciências.

Com Nóvoa (2017) interpretamos que é na busca pela sua maneira própria de ser professor que acontece a composição pedagógica. Três conhecimentos fazem parte dessa formação: o conhecimento da disciplina, o conhecimento pedagógico e a "[...] capacidade de compreender a "essência" do ensino, e sobre ela falar" (NÓVOA, 2017, p. 1127). Para tanto, se faz necessário o conhecimento prático da docência e "esse processo faz-se com os outros e valoriza o conhecimento profissional docente" (NÓVOA, 2017, p. 1128).

Interpretamos que o escrever sobre o fazer prático é importante para formação docente, pois traz à tona experiências da realidade da profissão, bem como permite uma relação com os outros, "assim sendo, é importante estimular, junto dos futuros professores e nos primeiros anos de exercício profissional, práticas de autoformação, momentos que permitam a construção de narrativas sobre as suas próprias histórias de vida pessoal e profissional" (NÓVOA, 2009, p. 39).

\section{REFLEXÃO SOBRE A DOCÊNCIA}

Frente a novos problemas originados de sua prática, os quais não conseguiu resolver no momento em que ocorriam, o futuro professor, com base em instrumentos teóricos, analisa a situação sistematicamente, envolvendo-se com a pesquisa e reflexão a posteriori sobre sua prática e o seu conhecimento acumulado sobre ela, de modo a resolver os problemas inicialmente detectados. Trata-se de desenvolver a dimensão da pesquisa no futuro professor (ARRUDA; PASSOS; FREGOLENTE, 2012, p. 32).

Essa atitude para pesquisa também foi possível observar na análise da produção científica, principalmente nos trabalhos mais extensos, como os artigos científicos. Pode-se observar nas justificativas relatadas para as práticas educativas que emergiram temas para reflexão e ampliação de estudos para resolver desafios do cotidiano, como (AE7) em que propuseram aos clubistas uma experiência de inclusão a partir da convivência com um integrante cego; ou (AE1) no estudo do sentido da palavra autonomia e como poderia ser potencializada nas práticas do Clube de Ciências, ou ainda de como os estudantes gostam de tecnologias e de que modo poderiam ser potencializadas no Clube (AE2), dentre outras.

Nesses trabalhos evidenciamos também um maior aprofundamento teórico, ampliando a descrição do como fazer para porque fazer assim no Clube de Ciências, na direção do que Nóvoa (2017) denomina de recomposição investigativa. Esta consiste em um processo investigativo do trabalho docente, visando a sua renovação. Isso precisa acontecer por meio "[...] de uma reflexão profissional própria, feita da análise sistemática do trabalho, realizada em colaboração com os colegas da escola" (NÓVOA, 2017, p. 1128).

Por fim, observamos uma variedade de autores estudados e referenciados nos artigos (25 obras diferentes). Em comum, todos os textos analisados apresentam citações, diretas ou indiretas, com o conceito de Clubes de Ciências e seus objetivos, com destaques para a obra de Mancuso, Lima e Bandeira (1996), que escreveram o primeiro livro acerca desses contextos de educação científica, e o capítulo de livro de Menezes e Schroeder (2014), que descrevem diferentes práticas educativas para os Clubes de Ciências. É importante mencionarmos que, a partir do ano de 2016, observamos nas publicações citações de artigos anteriores produzidos pelo próprio coletivo PIBID. Assim, os licenciandos e seus professores passaram também a serem autores referenciados em seus novos trabalhos sobre os Clubes de Ciências.

Outra perspectiva teórica que aparece em comum na produção científica analisada, especialmente em gêneros de artigos científicos, é a abordagem da Teoria Histórico-Cultural. As relações entre conceitos espontâneos e científicos, o papel do coordenador na mobilização de situações para aprendizagem e desenvolvimento dos clubistas, são tratadas particularmente com obras de Vigotski (1993, 2001). Inferimos que a escolha dessa abordagem teórica para reflexão das práticas nos Clubes de 
Ciências se deve aos estudos do coletivo do Subprojeto PIBID, com foco na formação humana via educação científica, que foram desenvolvidos com a orientação dos professores coordenadores na universidade.

Além disso, foi possível identificar na produção científica uma diversidade de referências empregadas para reflexões e interpretações das práticas educativas desenvolvidas em Clubes de Ciências. Conforme o objeto de estudo investigado, podemos observar obras sobre Educação Ambiental (R3, RE5, CL5); Iniciação e alfabetização científica (R2, R5, AE3); Mídias e outras Tecnologias (AE1, RE3); Inclusão (AES, CL3), Espaços educadores (AE5, R33), dentre outros. Com isso, interpretamos que ao propor a organização de diferentes práticas educativas e, posteriormente, a sua sistematização nas publicações criava-se no coletivo PIBID a necessidade da reflexão teórica, da consciência de suas experiências. Isso vai ao encontro do que Imbernón (2011, p.41) afirma: "Trata-se de formar o professor como um profissional prático-reflexivo que se defronta com situações de incerteza, contextualizadas e únicas, que recorre à investigação como uma forma de decidir e intervir praticamente em tais situações, que faz emergir novos discursos teóricos e concepções alternativas de formação."

Assim, podemos notar leituras comuns que permitem considerar uma reflexão do coletivo sobre os processos da aprendizagem e da docência em Clubes de Ciências, também reflexões teóricas acerca das especificidades das práticas educativas nesses contextos educativos, contribuindo para um rico repertório de referências das áreas de Ensino de Ciências e de Educação.

\section{COMUNIDADE DOCENTE}

$\mathrm{Na}$ análise da produção escrita do coletivo PIBID observamos que todos os textos eram elaborados por bolsistas ID/licenciandos; professores Supervisores/da escola pública e os coordenadores/professores da universidade. Com isso, interpretamos o que Arruda, Passos e Fregolente (2012, p. 32) afirmam sobre a importância do "estudante participar de atividades desenvolvidas em uma comunidade docente, aprender as práticas e a linguagem da docência com outros professores ou futuros professores, assimilando valores dessa comunidade e desenvolvendo a reflexão coletiva". Também nessa perspectiva, Nóvoa
(2017) defende a interposição profissional, ou seja, uma formação de professores que acontece em colaboração, através de contato com os profissionais mais experientes e com as vivências de cada profissão. Nessa lógica, "[...] a formação deve permitir a cada um construir a sua posição como profissional, aprender a sentir como professor" (NÓVOA, 2017, p. 1123), na relação com seus pares.

Imbernón (2009, p. 90) também parte da importância da formação docente na perspectiva de uma comunidade, considerando que:

Todos os agentes da
comunidade que se
relacionam com a escola
possuem conhecimento,
ninguém o tem na sua
totalidade. É necessário
compartilhar o
conhecimento de cada
um. Essa troca de
conhecimento entre os
agentes da comunidade
traz um enriquecimento
profissional. A formação
com a comunidade
permite uma forma
melhor de organização, o
que repercute na melhoria
da escola.

Assim, interpretamos, com base em Tomio, Schroeder e Rupp (2015), que a participação dos bolsistas ID em sua formação inicial e os professores supervisores em sua formação continuada em eventos científicos possibilitou: o compartilhamento das experiências aprendidas com outros colegas e professores; a capacidade de síntese no processo de construção dos saberes docentes; a capacidade de reflexão na ação; as habilidades de elaboração de gêneros textuais de comunicação científica e apresentação pública, com clareza, coesão, coerência e consistência teórico - prática; o exercício de leitura de pesquisas em ensino de Ciências a fim de desenvolver a atitude de atualizar-se nos conhecimentos da profissão docente e o desenvolvimento de um pertencimento em uma comunidade da Educação Científica.

Portanto, entendemos que escrever coletivamente acerca de suas práticas e compartilhá-las entre pares, em diferentes contextos sociais, pode favorecer a esse coletivo, o que destaca Nóvoa (2009, p. 40): “a 
competência colectiva é mais do que o somatório das competências individuais. Estamos a falar da necessidade de um tecido profissional enriquecido, da necessidade de integrar na cultura docente um conjunto de modos colectivos de produção e de regulação do trabalho", ou seja, a construção de noção de pertencimento a uma comunidade docente.

\section{IDENTIDADE DOCENTE E INTERESSE PELA DOCÊNCIA}

Conforme Gomes (2018, p. 44) podemos considerar que a identidade "[...] é construída a partir de uma relação entre os sujeitos, decorrente de sua capacidade de se reconhecerem e serem reconhecidos. Os sujeitos então sentem a necessidade de serem reconhecidos pelos outros. Para tanto, precisam se reconhecer. Só assim os outros o reconhecerão". Nessa direção, compreendemos que desenvolver a identidade de professor é processo permanente que integra diferentes experiências na construção do eu profissional que se transforma ao longo de suas carreiras.

Como destaca Marcelo (2009), esta construção da identidade docente se faz na relação com o outro, por isso tem igualmente uma dimensão coletiva, que se constitui nas condições concretas de trabalho, no exercício da profissão e em determinado contexto histórico e social. Assim, no que diz respeito à construção da identidade docente, interpretamos pela leitura dos escritos do coletivo PIBID que a (auto)formação e atuação docente no contexto do Clube de Ciências pôde: contribuir para perceberem-se professores pesquisadores; que o papel do professor é ser mediador do conhecimento, buscando soluções, construindo e enriquecendo conhecimento de modo conjunto com os estudantes e que se transformem em potenciais instrumentos na transformação de suas comunidades; que é um profissional da Educação e suas práticas educativas podem ser compartilhadas e construídas com outros sujeitos, para além dos muros escolares; que ser professor necessita de um olhar sensível, ético e estético no (seu) desenvolvimento e no exercício de sua profissão.

Para além dessas dimensões, compreendemos com Gomes (2018, p. 51) que a construção da identidade docente necessita da reflexão dos próprios professores (e licenciandos) sobre "[...] as formas de controle sobre o trabalho docente veiculadas pelas políticas de padronização (controle do Estado) quanto as práticas de contestação e resistência desencadeadas por docentes (sindicatos e associações docentes) [...]". Nessa perspectiva, identificamos um silenciamento na produção científica analisada do coletivo PIBID acerca dessas questões que perpassam a formação e prática docente, também no contexto de Clubes de Ciências que acontecem nas escolas.

Recorrendo a Imbernón (2009), é preciso entender que dimensões ligadas às condições de trabalho e o reconhecimento profissional são igualmente importantes no desenvolvimento da identidade docente. Trata-se de "analisar a formação como elemento de luta pelas melhorias sociais e profissionais e como promotora do estabelecimento de novos modelos relacionais na prática da formação e das relações de trabalho". (IMBERNÓN, 2009, p. 49).

Por fim, a construção da identidade docente também está ancorada ao interesse pela docência (ARRUDA; PASSOS; FREGOLENTE, 2012), ou como define Nóvoa (2017) à uma disposição pessoal, por isso a formação dos professores necessita de "[...] espaços e de tempos que permitam um trabalho de autoconhecimento, de autoconstrução. Precisamos de um acompanhamento, de uma reflexão sobre a profissão, desde o primeiro dia de aulas na universidade" (NÓVOA, 2017, p. 1121).

\section{CONSIDERAÇÕES FINAIS}

Nessa pesquisa objetivamos elucidar, a partir de uma análise da produção científica acerca de práticas docentes em Clubes de Ciências, desenvolvida pelo coletivo PIBID Subprojeto Ciências da Universidade Regional de Blumenau, contributos para a formação de professores em espaços de educação não formal.

A análise dos 65 trabalhos escritos e divulgados pelo coletivo permitiu interpretar que - movimento do PIBID, nas relações universidade-escola, potencializou os Clubes de Ciências constituírem-se espaços com possibilidade formativa, viabilizando aos licenciandos experiências que mobilizaram o interesse pela docência (disposição pessoal); o conhecimento prático da docência (composição pedagógica); a reflexão sobre a docência (recomposição investigativa); em estar uma comunidade docente (interposição profissional), bem como desenvolver a identidade docente.

Recorrendo ainda a Nóvoa (2017), compreendemos que o exercício da escrita 
científica e sua divulgação em eventos, também possibilitou um incremento a formação docente, desenvolvendo-se profissionalmente com o que o autor chama de exposição pública. Em um momento em que a escola procura cada vez mais a participação da sociedade nas questões educativas, o professor precisa "[...] conquistar uma posição no seio da profissão, [...]tomar posição, publicamente, sobre os grandes temas educativos e participar na construção das políticas públicas. É aprender a intervir como professor. (NÓVOA, 2017, p. 1130).

Com a pesquisa dessa produção escrita dos licenciandos, concluímos que o Clube de Ciências como contexto de ENF, constitui-se um locus para percursos de formação docente, oportunizando aos futuros professores saberes específicos na organização de experiências coletivas de aprender que rompem com 0 modelo escolar de formação e seus modos de relação com o saber. Nos clubes as relações sociais entre professor de Ciências e estudantes são mais horizontais, exigem habilidades dos docentes de escuta aos interesses, valorização do planejamento coletivo com eles, bem como o desenvolvimento de práticas investigativas em que compartilham as experiências de conhecer. Além disso, a elaboração conceitual sempre parte de temas do contexto dos estudantes ou de atualidades do mundo, o que remete para um ensino de Ciências contextualizado e com sentido aos estudantes. Pressupomos que essas habilidades são fundamentais ao professor do nosso tempo!

Tal constatação oportuniza (à universidade e a outros agentes de formação) desenvolvermos processos de formação docente capazes de contemplar a educação em diferentes contextos, além da escola, e principalmente na relação com ela.

Concluímos que, nas especificidades do conhecimento elaborado acerca das contribuições dessa experiência de formação docente em Clubes de Ciências, pode-se ampliar a reflexão para a necessidade das universidades, nos cursos de licenciaturas, aprender mais sobre outros contextos de formação docente, incorporando-a nos seus currículos, em estágios, projetos de extensão e pesquisa, de modo a ampliar oportunidades formativas e de atuação profissional de educadores para outros espaços sociais de educação de nossa contemporaneidade.
Por fim, com o relato dessa pesquisa reiteramos, como tantos outros estudos de pesquisadores brasileiros, o valor do PIBID na formação inicial docente de nossos licenciandos brasileiros. Ao mesmo tempo, com esse conhecimento sistematizado, expressamos nossa resistência às descontinuidades de programas e políticas públicas na área da Educação, que rompem com práticas efetivas e de sucesso na formação docente e nas práticas educativas em escolas e outros contextos de ENF, em nosso país.

\section{AGRADECIMENTOS}

Ao PIBIC CNPq pelo apoio à iniciação científica com a concessão de bolsa de pesquisa para uma das autoras licenciandas; Ao FUMDES Santa Catarina com a concessão de bolsa de pesquisa para uma das autoras mestrandas em Educação; À CAPES, com a concessão de bolsas ao PIBID para autores que foram Coordenadores e Bolsista de Iniciação à Docência no Subprojeto Ciências e à Divisão de Apoio a Extensão FURB pela bolsa para ações extensionistas com os Clubes de Ciências. Essas agências facilitaram as condições para realização de uma investigação coletiva que articulou saberes de práticas de docência com a extensão e a pesquisa.

\section{REFERÊNCIAS}

ARRUDA, S. de M.; PASSOS, M. M.; FREGOLENTE, A. Focos da Aprendizagem Docente. Alexandria Revista de Educação em Ciência e Tecnologia, Florianópolis, v. 5, n. 3, p. 25-48, nov. 2012. Disponível em: https://periodicos.ufsc.br/index.php/alexandria/ article/view/37734 . Acesso em: 25 ago. 2020.

CAPES - COORDENAÇÃO DE APERFEIÇOAMENTO DE PESSOAL DE NÍVEL SUPERIOR. Portaria no 096, de 18 de julho de 2013. Regulamento do Programa Institucional de bolsa de iniciação à Docência. Brasília, 2013. 24p.

CASTRO, F. R. de. Há sentido na educação não formal na perspectiva da formação integral? Museologia \& Interdisciplinaridade, Brasília, v. 4, n. 8, dez. 2015. Disponível em: https://periodicos.unb.br/index.php/museologia/ article/view/17166. Acesso em: 20 ago. 2020. DOI: $10.26512 /$ museologia.v4i8.17166

GOHN, M. da G. Educação Não Formal e o educador social: Atuação no desenvolvimento de projetos sociais. São Paulo: Cortez, 2010. 
Disponível

em:

http://revistas.cesgranrio.org.br/index.php/meta avaliacao/article/view/1. Acesso em: 20 ago. 2020. DOI: $\underline{10.22347 / 2175-2753 v 1 i 1.1}$

GOMES, A. A. Conceito de identidades e a identidade profissional docente. Colloquium Humanarum, Presidente Prudente, v. 15, n. 3, p. 42-53, dez. 2018. Disponível em: http://journal.unoeste.br/index.php/ch/article/vi ew/2481. Acesso em: 20 ago. 2020. DOI: 10.5747/ch.2018.v15.n3.h372

IMBERNÓN, F. Formação permanente do professorado: novas tendências. São Paulo: Cortez, 2009.

IMBERNÓN, F. Formação docente e profissional formar-se para a mudança e a incerteza. São Paulo: Cortez, 2011.

LIMA, M. C. Monografia: a engenharia da produção acadêmica. 2. ed. São Paulo: Saraiva, 2008.

MANCUSO, R.; LIMA, V. do Rosário; BANDEIRA, V. A. Clubes de Ciências: criação, funcionamento, dinamização. Porto Alegre: Cecirs, 1996.

MARCELO, C. Desenvolvimento profissional docente: passado e futuro. Sísifo - Revista de Ciência da Educação, Lisboa, p.7-22, jan./ fev./ mar./ abr. 2009. Disponivel em: http://sisifo.ie.ulisboa.pt/index.php/sisifo/article /view/130. Acesso em: 20 ago. 2020.

MENEZES, C.; SCHROEDER, E. Clubes de Ciências: contribuições para a educação científica e o desenvolvimento da criatividade nas escolas. In: SCHROEDER, E.; SILVA, V. L. de S. (Orgs.). Novos Talentos: Processos Educativos em Ecoformação. Blumenau: Editora Legere, 2014. p. 147-175.

NÓVOA, A. S. Professores: Imagens do futuro presente. Lisboa: Educa, 2009.

NÓVOA, A. S. Firmar a posição como professor, afirmar a profissão docente. Cadernos de Pesquisa, São Paulo, v. 47, n. 166, p. 1106-1133, out./dez. 2017. Disponível em: https://www.scielo.br/scielo.php?pid=S0100$15742017000401106 \&$ script=sci abstract \&tlng=pt. Acesso em: 20 ago. 2020. DOl: $\underline{10.1590 / 198053144843}$
PRÁ, G.; TOMIO, D. Clube de Ciências: condições de produção da pesquisa em educação científica no Brasil. Alexandria - Revista de Educação em Ciência e Tecnologia, Florianópolis, v. 7, n. 1, p. 179-207, mai. 2014. Disponível em: https://periodicos.ufsc.br/index.php/alexandria/ article/view/38208/0. Acesso em: 20 ago. 2020.

ROCHA, N. M. et al. Como seria se não fosse como é: compartilhando a experiência da inclusão inversa em Clubes de Ciências. In: ENCONTRO REGIONAL SUL DO ENSINO DE BIOLOGIA, 7., Criciúma, 2015, Anais... Criciúma: UNESC, 2015.

ROCHA, N. M.; MELO, E. J.; TOMIO, D. A construção coletiva de um "espaço" de aprendizagem em um Clube de Ciências. In: COLÓQUIO LUSO-BRASILEIRO DE EDUCAÇÃO, 2., Joinville, 2016, Anais... Joinville: UDESC; Braga: Universidade do Minho, 2016.

TOMIO, D.; SCHROEDER, E.; RUPP, A. A formação inicial de professores na atuação em Clubes de Ciências: uma experiência no PIBID. In: ENCONTRO REGIONAL SUL DO ENSINO DE BIOLOGIA, 7., Criciúma, 2015, Anais... Criciúma: UNESC, 2015. Disponivel em: https://www.scielo.br/scielo.php?script=sci artte xt\&pid=S1983-21172019000100312\&tlng=pt. . Acesso em: 20 ago. 2020.

TOMIO, D.; HERMANN, A. Mapeamento dos clubes de ciências da América Latina e construção do site da Rede Internacional de Clubes de Ciências. Revista Ensaio, Belo Horizonte, v. 21, p. 1-23, 2019. Disponível em: https://www.scielo.br/scielo.php?script=sci artte xt\&pid=S1983-21172019000100312. Acesso em: 20 ago. 2020.

SANTOS, A. R. Metodologia Científica: a construção do conhecimento. 3. ed. Rio de Janeiro: DP\&A Editora, 2000.

SEVERO, J. L. R. de L. Educação não escolar como campo de práticas pedagógicas. Revista Brasileira de Estudos Pedagógicos. (on-line), Brasília, v. 96, n. 244. p. 561-576, set/dez. 2015. Disponível em: https://www.scielo.br/scielo.php?script=sci artte xt\&pid=S2176$66812015000300561 \& \operatorname{lng}=e n \& n r m=i s o . \quad$ Acesso em: 20 ago. 2020. DOI: 10.1590/S2176- 
VIGOTSKI, L. S. Pensamento e Linguagem. São Paulo: Grupo A, 1993.

VIGOTSKI, L. S. A construção do pensamento e da linguagem. São Paulo: Martins Fontes, 2001.
ZUCCHETTI, D. T. Resenha. Educação, Porto Alegre, v. 35, n. 1, p. 137-138, jan./abr. 2012. Disponível em: https://revistaseletronicas.pucrs.br/ojs/index.ph $\mathrm{p} /$ faced/article/view/9299. Acesso em: 20 ago. 2020.

Apêndice A - Roteiro de leitura

\begin{tabular}{|c|c|l|l|}
\hline \multicolumn{2}{|c|}{ UNIDADES DE ANÁLISE } & \multicolumn{2}{|l|}{ PRODUÇÃO ESCRITA DO COLETIVO PIBID CIÊNCIAS } \\
\multicolumn{1}{|c|}{ FURB }
\end{tabular}

Fonte: Os autores. 